\title{
Catalytic and Thermal Cracking of Bio-Oil from Oil-Palm Empty Fruit Bunches, in Batch Reactor
}

\author{
Santiyo Wibowo*, Lisna Efiyanti, and Gustan Pari \\ Forest Product Research and Development Center, Ministry of Environment and Forestry Republic of Indonesia, \\ Jl. Gunung Batu No. 5, Bogor 16610, West Java, Indonesia
}

* Corresponding author:

tel: $+62-251-8633378$

email:santiyowibowo1973@yahoo.co.id

Received: March 11, 2019

Accepted: December 4, 2019

DOI: $10.22146 /$ ijc. 44076

\begin{abstract}
The world's potency of fossil-derived petroleum fuels has declined steadily, while its consumption continues to rise ominously. Therefore, several countries have started to develop renewable fuels like bio-oil from biomass. Relevantly, the aim of this research was to explore the technical feasibility of upgrading the qualities of crude bio-oil (CBO) produced from the pyrolysis on oil-palm empty fruit bunches (OPEFB) using $\mathrm{Ni} / \mathrm{NZA}$ catalyst in a batch reactor. The natural zeolite (NZ) was activated by HCL $6 \mathrm{~N}$ and $\mathrm{NH}_{4} \mathrm{Cl}$ (obtained sample $\mathrm{NZA}$ ). Supporting $\mathrm{Ni}$ onto $\mathrm{NZA}$ was conducted with an impregnation method using a salt precursor of $\mathrm{Ni}\left(\mathrm{NO}_{3}\right)_{2} \cdot 6 \mathrm{H}_{2} \mathrm{O}$ followed by calcination with a temperature of $500{ }^{\circ} \mathrm{C}$. Catalyst characterization includes determining the site of $\mathrm{TO}_{4}(\mathrm{~T}=\mathrm{Si}$ or $\mathrm{Al})$ in zeolites, acidity, crystallinity, and catalyst morphology. Cracking reaction of $C B O$ was carried out in batch reactor in varied temperatures of 250 and $300{ }^{\circ} \mathrm{C}$ with the variation of catalyst weight of $0,4,6$, and $8 \%$ toward CBO. Several analyses of the liquid product such as product yield, specific gravity, $p H$, viscosity, calorific value, and chemical compound were conducted. The results showed that acidification and Ni loading on zeolite samples increased their acidity. The optimum CBO's cracking condition was judged to be the temperature of $300{ }^{\circ} \mathrm{C}$ with $6 \% \mathrm{Ni} / \mathrm{NZA}$ catalyst use, whereby the fuel yield reached $26.42 \%$ and dominated by particular compounds comprising phenol, octanoic acid, and alkane hydrocarbons. Under such conditions, the characteristics of fuel were pH 3.54, specific gravity 0.995, viscosity $14.3 \mathrm{cSt}$, and calorific value $30.85 \mathrm{MJ} / \mathrm{kg}$.
\end{abstract}

Keywords: fossil fuels; renewable biomass-derived fuels; oil-palm empty fruit bunches; crude bio-oil (CBO); upgrading; catalyst cracking; CBO's fuel

\section{- INTRODUCTION}

The fossil-derived fuels, particularly petroleum oils, cannot be renewed and might inflict harmful effects on the environment. Besides, their formation may take considerable ages. Recently, worldwide petroleum oil production, including in Indonesia, continues to decline steadily, while the need for such fuel oil increases almost every year. This situation requires the findings of alternative materials as the replacement for fossil fuels, which are almost limitless in supply and renewable, such as solar energy, water/marine energy, wind power, geothermal power, atomic/nuclear energy, and biomass.

Biomass is one of the promising and considered alternative energy materials as a natural resource that can be renewed, which more environmentally friendly. The biomass also contains carbon $(\mathrm{C})$ and hydrogen $(\mathrm{H})$ elements, of which burning releases energy but exhibits unique characteristics and enacts the related interests, as among others exemplified in the following details. Biomass sources being renewable are abundantly available, especially from agricultural and forestry wastes in the form of woods and other lignocellulose matters [1].

One kind of the biomass-derived fuels which afford the potentiality to be developed prospectively and beneficially is bio-oil. Bio-oil could be in the shape of liquid fuels, and the biomass sources for such bio-oil are among other agricultural and forestry by-products, crops, and municipal wastes through further biochemical or thermochemical processes [2]. Bio-oil is 
a thermally unstable mixture containing hundreds of oxygenated organic compounds [3]. This high content of such oxygenated matters increases the polar nature of the bio-oils, rendering their hygroscopicity and therefore limits its mixing ability with inherently less- or non-polar hydrocarbon fuels [4].

Some pathways that can be used to improve the qualities of crude bio-oil are through several various upgrading processes such as catalytic cracking, hydrocracking, or hydrodeoxygenation [5]. Liu et al. [6] reported that some researches had been conducted for the upgrading of bio-oil using $\mathrm{Fe}, \mathrm{Zn}, \mathrm{Al}$, and $\mathrm{Mg}$ metal catalysts at ambient temperature under open atmospheric pressure. Results revealed that such metal catalysts improved the quality of resulting upgraded bio-oil (fuel), whereby its $\mathrm{pH}$ raised from 3.53 to 4.85 , which could decrease the corrosive nature of bio-oil.

Another metal that is also often used in the cracking reaction is $\mathrm{Ni}$ because it has good results and selectivity for the desired product [7]. However, Ni metal has several disadvantages when it is used directly, considering the high price, low surface area, and sintering can occur during the reaction. Other materials, as support such as zeolite, are required to improve catalyst performance and make a bifunctional catalyst. Natural zeolite is a porous material whose availability is abundant so that it has a high potential and occupies a special place to be used as a catalyst support material [8]. The use of natural zeolite impregnated with $\mathrm{Ni}, \mathrm{Mo}$, and Co was conducted by Sriningsih et al. [9] on hydrocracking of LDPE plastics waste. In this research, the highest gasoline conversion percentage is reached about $71.49 \%$ at a temperature of $350{ }^{\circ} \mathrm{C}$ with $\mathrm{H}_{2}$ flow of $20 \mathrm{~mL} / \mathrm{min}$ for $1 \mathrm{~h}$. It is also shown that the composition of the product is paraffins, olefins, and naphthenes.

Yang et al. [10] reported the working on the upgrading of bio-oil into fuel, which was produced from shrubs residues, through the cracking process using Zeolite H-ZSM-5 catalyst. Results showed that the quality of bio-oil-converted fuel improved after such catalytic cracking, whereby its oxygen content $(\mathrm{w} / \mathrm{w})$ decreased from 47.61 to $31.83 \%$ and its moisture content (w/w) decreased from 33.23 to $22.15 \%$.

Relevantly, the aim of this research was to investigate the technical feasibility of upgrading the qualities and characteristics of $\mathrm{CBO}$ previously produced from OPEFB, through the CBO's cracking into fuel, with Ni/NZA as a catalyst and entirely under open atmospheric pressure.

\section{- EXPERIMENTAL SECTION}

\section{Materials}

The main material for bio-oil manufacture was fresh oil-palm empty fruit bunches (OPEFB). The OPEFB samples were obtained from the palm-oil factory, located in Lebak District, Banten Province. The natural zeolite was obtained from Bayah, Lebak-Banten. Meanwhile, the chemical matters used were $\mathrm{AgNO}_{3}$ (Merck), hydrochloric acid (Merck), $\mathrm{NH}_{4} \mathrm{Cl}$ (Merck), $\mathrm{Na}_{2} \mathrm{SO}_{4}$ (Merck), $\mathrm{Ni}\left(\mathrm{NO}_{3}\right)_{2} \cdot 6 \mathrm{H}_{2} \mathrm{O}$ (Merck).

\section{Instrumentation}

The FTIR spectra were recorded on a Shimadzu (FTIR-8201-FC) spectrophotometer; the XRD diffractograms were recorded on a Shimadzu XRD7000. The GC-MS chromatogram and spectra were recorded on a Shimadzu QP-2010 Ultra. The SEM images were recorded on a Zeiss EVO 50, sieve shaker (Retsch), bomb calorimetry Toshniwal DT 100, viscometer (Brookfield LVF), fixed bed reactor, analytical balance (Ohaus), oven (Memmert), distillation apparatus, stirrer, desiccator, $\mathrm{pH}$ meter (Hanna), pycnometer, Erlenmeyer and other glassware.

\section{Procedure}

\section{OPEFB pyrolysis}

OPEFB samples were dried and cut into small pieces with a crusher. The resulting small-sized OPEFB were ready to use for fast pyrolysis process to obtain $\mathrm{CBO}$ product. For such, $500 \mathrm{~g}$ of sample OPEFB (moisture content, i.e., $10-15 \%$, dry basis) was put into the pyrolysis reactor at a temperature of $550{ }^{\circ} \mathrm{C}$ [11]. After the pyrolysis, the mixed liquid (water and bio-oil) was collected as crude bio-oil (CBO). 


\section{Preparation of Ni/NZA}

The preparation of the catalyst that incorporated zeolite referred to the procedure performed from the previous study [12]. The natural zeolite is crushed and then sieved using a sieve of 100 mesh, washed using distilled water, and then dried at a temperature of $120^{\circ} \mathrm{C}$ (obtained sample is named as NZ). NZ was activated with $6 \mathrm{~N}$ hydrochloric acid for $30 \mathrm{~min}$ at reflux temperature. The resulting solid was filtered and washed with distilled water to neutral and showed a negative test for the presence of $\mathrm{Cl}^{-}$ions using the $\mathrm{AgNO}_{3}$ solution. The residue was dried at a temperature of $100-120^{\circ} \mathrm{C}$. The sample was refluxed in the $\mathrm{NH}_{4} \mathrm{Cl}$ solution for $3 \mathrm{~h}$ at a temperature of $90^{\circ} \mathrm{C}$. The resulting solid was filtered and dried at a temperature of $100-120^{\circ} \mathrm{C}$ to obtain activated natural zeolite (NZA).

Loading $\mathrm{Ni}$ onto NZA was conducted with the impregnation method using a salt precursor of 3\% $\mathrm{Ni}\left(\mathrm{NO}_{3}\right) 6 \mathrm{H}_{2} \mathrm{O}$ to NZA (w/w) followed by calcination using the reactor with a temperature of $500{ }^{\circ} \mathrm{C}$ for $60 \mathrm{~min}$ (obtained sample Ni/NZA). Catalyst characterization includes determining the site of $\mathrm{TO}_{4}(\mathrm{~T}=\mathrm{Si}$ or $\mathrm{Al})$ in zeolites observed with Fourier Transform Infrared Spectroscopy (FT-IR Shimadzu, Prestige-21), acidity using ammonia adsorption, crystallinity using X-ray diffraction (XRD Shimadzu 7000), and catalyst morphology using a scanning electron microscope (SEM Zeiss EVO 50).

Measurement of the catalyst acidity was carried out by flowing ammonia vapor for $24 \mathrm{~h}$ at room temperature on the catalyst sample. The acidity of the catalyst was calculated as the weight difference of the catalyst sample before and after adsorption, using the following equation: Acidity $(\mathrm{A}: \% \mathrm{w} / \mathrm{w})=\frac{\mathrm{W} 3-\mathrm{W} 2}{(\mathrm{~W} 2-\mathrm{W} 1) \mathrm{M}} \times 1000 \mathrm{mmol} / \mathrm{g}$

where A is the acidity of catalyst ( $\mathrm{mmol} / \mathrm{g}$ zeolite), W1 is the weight of an empty porcelain cup that has been heated (g), W2 is the weight of the cup aided of the catalyst before adsorption (g), W3 is the weight of cup and sample of the catalyst after adsorption (g), and $\mathrm{M}$ is the molecular weight of the base ammonia $(\mathrm{g} / \mathrm{mol})$.

\section{Cracking $C B O$ in a batch reactor}

Cracking of $\mathrm{CBO}$ was performed in a batch reactor (reactor has a capacity of $500 \mathrm{~mL}$, and is equipped with heater, condenser and thermocouple) with weight of $\mathrm{Ni} / \mathrm{NZA}$ i.eA $\mathrm{A}_{1}=0 \%$ (control), $\mathrm{A}_{2}=4 \%, \mathrm{~A}_{3}=6 \%$ and $\mathrm{A}_{4}$ $=8 \%$ toward $\mathrm{CBO}$ at temperature of $\mathrm{B}_{1}=250{ }^{\circ} \mathrm{C}$ and $\mathrm{B}_{2}$ $=300{ }^{\circ} \mathrm{C}$ for $2 \mathrm{~h}$ and replicated 3 times, respectively. The physicochemical properties of the liquid products were analyzed to obtain yield gravimetrically, specific gravity by pycnometer method, $\mathrm{pH}$ by $\mathrm{pH}$ meter, viscosity by Brookfield LVF viscometer, calorific value by bomb calorimetry Toshniwal DT 100 and chemical component product by GCMS Shimadzu QP 2010 Ultra. As a comparison, the $\mathrm{CBO}$ from the OPEFB pyrolysis was also examined for its characteristics similarly.

\section{- RESULTS AND DISCUSSION}

\section{Characteristics of Zeolite-Related Catalyst}

Table 1 discloses the results of total acidity analysis on the NZ, NZA, and Ni/NZA samples, which corresponded to $0.85,1.20$, and $1.70 \mathrm{mmol} / \mathrm{g}$, respectively. It appears that the total acidity of $\mathrm{Ni} / \mathrm{NZA}$ catalyst was the largest, followed in decreasing order by $\mathrm{NZA}$, and NZ (the lowest).

Total acidity is calculated by the amount of chemically adsorbed $\mathrm{NH}_{3}$ per unit weight of the sample. The amount of ammonia adsorbed on zeolite is obtained from the difference in weight of zeolite before and after the adsorption. Acidity measured in this research is the total acidity of the catalyst sample, namely Brønsted and Lewis acid. This is because ammonia has a small molecular size (molecular weight of $17 \mathrm{~g} / \mathrm{mol}$ ), so it can be adsorbed into the zeolite pore. Zeolites have small-pore sizes in the range of $0.30-0.45 \mathrm{~nm}$ [13]. Loading Ni onto NZA increased Brønsted and Lewis acid sites; therefore, Ni/NZA catalysts

Table1. Total acidity of NZ, NZA and Ni/NZA

\begin{tabular}{lc}
\hline Sample & Acidity $(\mathrm{mmol} / \mathrm{g})$ \\
\hline $\mathrm{NZ}$ & 0.8494 \\
$\mathrm{NZA}$ & 1.1963 \\
$\mathrm{Ni} / \mathrm{NZA}$ & 1.7006 \\
\hline
\end{tabular}




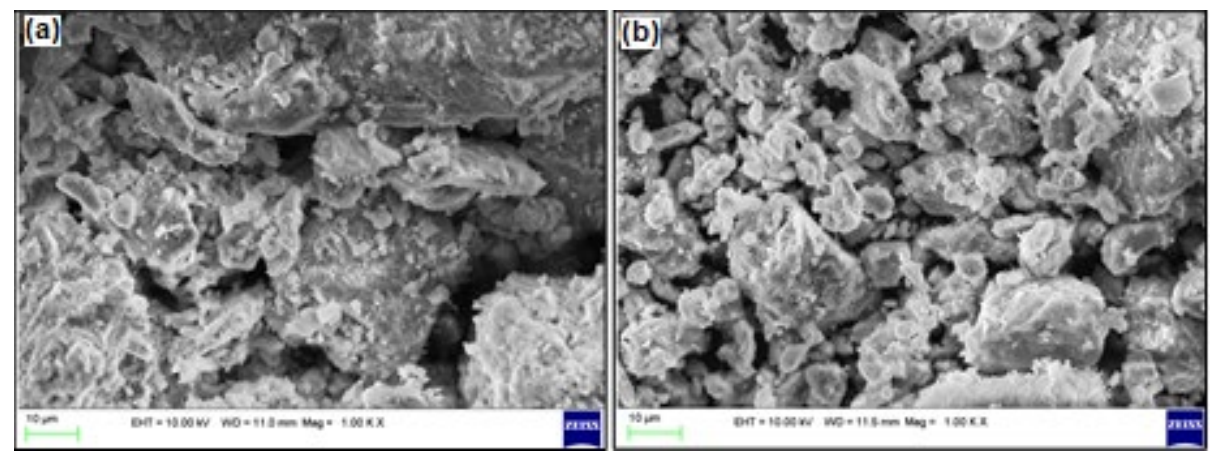

Fig 1. SEM results on the visual morphology image of (a) NZ and (b) Ni/NZA

had the greatest acidity. Ni metal is highly coordinated (has an ability to bind with ligand due to the arrangement of electron potential from unoccupied d-orbital), which has many low-energy orbitals and can act as a Lewis site. This result was in accordance with the result obtained by Trisunaryanti et al. [14], that loading of $\mathrm{Co}, \mathrm{Ni}$, and $\mathrm{Pd}$ metals onto mordenite could increase the number of both Brønsted and Lewis acid sites. According to Naqvi et al. [15], increasing acidity of catalysts can facilitate converting biomass into an organic compound with lower molecular weight. An almost similar situation occurred in this research, whereby the use of Ni/NZA catalyst during $\mathrm{CBO}$ cracking into fuel brought out more numerously the fragmented and lower molecular weight organic compounds in the product, thereby contributing greatly to the increased fuel yield, compared to the cracking without catalyst (Table 2).

Fig. 1(a) and 1(b) reveal the SEM images of NZ and $\mathrm{Ni} / \mathrm{NZA}$ catalyst visually. From this figure, we can see the porous character and sphere-like crystals of the catalyst. Ni particles were less dispersed in catalyst because we can find the large Ni particles on the surface and Ni particle agglomeration tend to occur after the impregnation process.

The XRD results of NZ and Ni/NZA catalysts are disclosed in Fig. 2. From this figure, the $2 \theta$ that appears in the sample can be identified through comparison with mordenite and clinoptilolite type at JCPDS data. It strongly indicates that the NZ could be classified as mordenite (m) mineral, which constituted the NZ's main component and still contained clinoptilolite $(\mathrm{kl})$ and quartz (k) (Fig. 2). Salim et al. [16] conducted zeoliterelated research and came out with a similar conclusion that natural zeolite contained mordenite, clinoptilolite, and quartz. Mordenite crystal is chemically a neutral basic structure and exhibits high resistance against high temperatures [17].

Metal impregnation into the zeolite causes decreasing of the crystallinity of NZA (crystallinity of NZA and Ni/NZA are 90.15 and $87.09 \%$, respectively). It occurred because of the high temperature calcination process, making damage to the structure, and also less dispersed Ni on zeolite.

The successful Ni-metal loading onto the zeolite was shown by the obvious diffraction line at $29.68^{\circ}$ (Fig. 2). This peak was sharp and strong enough, indicating that the active Ni sites were less dispersed on the support (also in line with SEM observation shown in Fig. 1). This is consistent with Yao et al. [18] research that the diffraction lines of $\mathrm{Ni}$ metal were weak and broad, indicating that the $\mathrm{Ni}$ was well dispersed in the support material.

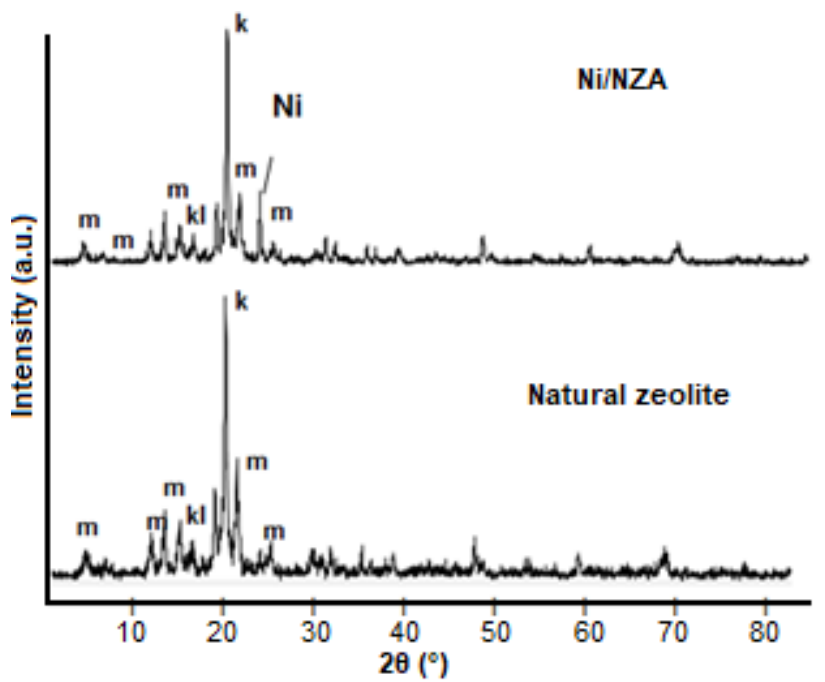

Fig 2. XRD's diffractograph of NZ and Ni/NZA catalyst 
Fig. 3 depicts the comparison of the FTIR spectra between natural zeolite (NZ) and Ni/NZA catalyst. For a zeolite in common, the typical absorption band of its structure was found in the wavenumber at $795 \mathrm{~cm}^{-1}$. Such a particular wavenumber was due to the bending absorption of the $\mathrm{Si}-\mathrm{O}$ bond on the external zeolite framework. The vibration of $\mathrm{Si}-\mathrm{O} / \mathrm{Al}-\mathrm{O}$ bonds at the area in the range of $420-500 \mathrm{~cm}^{-1}$ of FTIR spectra appeared at 465 and $463 \mathrm{~cm}^{-1}$ for the NZ and Ni/NZ, respectively.

The absorption bands at $3000-4000 \mathrm{~cm}^{-1}$ disclose the vibration of $\mathrm{O}-\mathrm{H}$ hydroxyl inside the zeolite structure. The O-H group at $3449 \mathrm{~cm}^{-1}$ in the FTIR spectra was due to the adsorbed water molecule on the zeolite for the $\mathrm{Ni} / \mathrm{NZA}$ catalyst. Further, the absorption bands at $1639 \mathrm{~cm}^{-1}$ reveal the vibration caused by the $\mathrm{OH}$-group buckling in water molecules, which was adsorbed into the natural zeolite as well as into $\mathrm{Ni} / \mathrm{NZA}$ catalyst.

From Fig. 3, it also can be seen that there was a peak shift at $1000-1100 \mathrm{~cm}^{-1}$, which showed the absorption due to the asymmetrical vibration of the $\mathrm{TO}_{4}$ group to larger wavenumber. In NZ spectra, a vibrational region of $\mathrm{TO}_{4}$ showed a peak of $1043 \mathrm{~cm}^{-1}$ whereas on Ni/NZA at $1051 \mathrm{~cm}^{-1}$. In zeolite, this shift occurred due to decreasing of $\mathrm{Al}$ atoms in zeolite framework in the dealumination process by $\mathrm{HCl}$; therefore, the distance between the $\mathrm{Al}$ atoms will be further away, and $\mathrm{Al}$ atoms interaction will decrease, and it can be easier to move. This is similar to Ichsan et al. [19] that the shift of asymmetric vibration occurred after the impregnation of $\mathrm{Ni}$ into zeolite, and the band at $1045.46 \mathrm{~cm}^{-1}$ shifted to $1092.72 \mathrm{~cm}^{-1}$ for zeolite and NiMO/ZA, respectively.

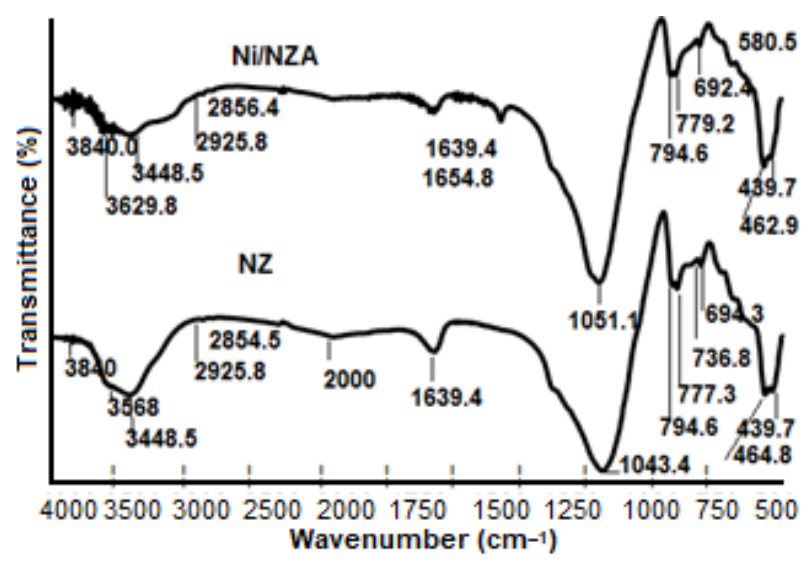

Fig 3. FTIR spectra of $\mathrm{NZ}$ and $\mathrm{Ni} / \mathrm{NZA}$

\section{Characteristics of the Upgraded Crude Bio-Oil}

\section{The yield of the upgraded crude bio-oil}

The yield of CBO derived fuel, which was free of water, ranged about $1.52-26.42 \%$ (Table 2). The highest yield $(26.42 \%)$ was obtained with a $6 \% \mathrm{Ni} / \mathrm{NZA}$ catalyst at $300^{\circ} \mathrm{C}$. Meanwhile, the lowest fuel yield was obtained without a catalyst at $250^{\circ} \mathrm{C}$. The CBO's cracking at $250^{\circ} \mathrm{C}$, either with or without Ni/NZA catalyst, exhibited low fuel yield (1.52-3.91\%). Accordingly, the CBO's cracking at $250{ }^{\circ} \mathrm{C}$ did not run optimally. The possible explanation is that because the collision between the involved reactants during the cracking at such low temperatures might not proceed effectively.

On the other hand, the CBO's cracking at higher temperatures $\left(300^{\circ} \mathrm{C}\right)$, either with $\mathrm{Ni} / \mathrm{NZA}$ catalyst (4$8 \%$ ) or without catalyst ( $0 \%$ ), brought out the higher fuel yield (20.32-26.42\%). This can be explained as because the CBO's cracking could occur more intensively at $300^{\circ} \mathrm{C}$, thereby converting more of CBO's high molecularweight chemical components through degradation and other chemical breakdowns to numerously simpler and lower molecular weight compounds, all in produced fuel, increasing the fuel yield. The addition of Ni/NZA catalyst to the CBO's cracking could increase the fuel yield (1.92-26.42\%) when compared with the cracking without catalyst (1.52-20.32\%). According to Hessel et al. [20], the use of catalysts could decrease the reaction temperature, and hence, it was able to reduce the reaction's energy, and it could also provide more active sites for the reaction process.

A catalyst could accelerate the reaction rate and improves the quantity as well as the quality of the reaction product. Besides, the catalyst might also enhance the selectivity of the reaction course toward releasing the desired final products. Accordingly, such a situation will allow the reaction to take place rapidly or to decrease the temperature due to the changes otherwise triggered by the reagents. Relevantly, in this research results, it is indicated that the use of Ni/NZA catalyst indeed accelerated the CBO's cracking reaction and induced reaction selectivity, thereby intensifying the CBO's chemical conversion and increasing the yield of the desired product. 
Table 2. Characteristics of the upgraded CBO into fuel

\begin{tabular}{cccccccccc}
\hline $\begin{array}{c}\text { Code for } \\
\text { treatment } \\
\begin{array}{c}\text { combination in the } \\
\text { cracking } \\
\text { (AB) }\end{array}\end{array}$ & $\begin{array}{c}\text { Mixed } \\
\text { liquid } \\
(\%)\end{array}$ & $\begin{array}{c}\text { Water-free } \\
\text { liquid (fuel) } \\
(\%)\end{array}$ & $\begin{array}{c}\text { Water } \\
(\%)\end{array}$ & $\begin{array}{c}\text { Residue } \\
(\%)\end{array}$ & $\begin{array}{c}\text { Conversion } \\
(\%)\end{array}$ & $\begin{array}{c}\text { pH } \\
\text { Physical properties }\end{array}$ & $\begin{array}{c}\text { Specific } \\
\text { gravity }\end{array}$ & $\begin{array}{c}\text { Viscosity } \\
(\mathrm{cSt})\end{array}$ & $\begin{array}{c}\text { Calorific } \\
\text { value } \\
(\mathrm{MJ} / \mathrm{kg})\end{array}$ \\
\hline Raw bio-oil & - & - & - & & & 2.70 & 1.072 & 57.7 & - \\
$\mathrm{A}_{1} \mathrm{~B}_{1}$ & 6.67 & 1.52 & 5.15 & 84.19 & 15.81 & 2.86 & 1.001 & 11.5 & 17.22 \\
$\mathrm{~A}_{1} \mathrm{~B}_{2}$ & 24.87 & 20.32 & 4.55 & 62.36 & 34.64 & 3.16 & 0.999 & 21.3 & 22.24 \\
$\mathrm{~A}_{2} \mathrm{~B}_{1}$ & 9.43 & 1.92 & 7.51 & 83.29 & 16.71 & 3.15 & 0.998 & 9.5 & 18.94 \\
$\mathrm{~A}_{2} \mathrm{~B}_{2}$ & 30.72 & 25.62 & 5.10 & 57.15 & 42.85 & 3.53 & 0.994 & 11.17 & 29.49 \\
$\mathrm{~A}_{3} \mathrm{~B}_{1}$ & 10.06 & 3.90 & 6.16 & 81.69 & 18.31 & 3.43 & 0.996 & 9.7 & 22.65 \\
$\mathrm{~A}_{3} \mathrm{~B}_{2}$ & 30.65 & 26.42 & 4.23 & 56.59 & 43.40 & 3.54 & 0.995 & 14.3 & 30.85 \\
$\mathrm{~A}_{4} \mathrm{~B}_{1}$ & 8.88 & 3.56 & 5.32 & 80.81 & 19.19 & 3.31 & 0.992 & 9.8 & 27.46 \\
$\mathrm{~A}_{4} \mathrm{~B}_{2}$ & 30.65 & 26.12 & 4.53 & 59.29 & 40.71 & 3.53 & 0.990 & 15 & 28.59 \\
\hline
\end{tabular}

Remarks:

Treatment combination (AB) implemented in the cracking, as follows:

$\mathrm{A}_{1} \mathrm{~B}_{1}=$ Non catalyst, $250^{\circ} \mathrm{C}$ temperature

$\mathrm{A}_{1} \mathrm{~B}_{2}=$ Non catalyst, $300^{\circ} \mathrm{C}$ temperature

$\mathrm{A}_{2} \mathrm{~B}_{1}=4 \%$ catalyst, $250^{\circ} \mathrm{C}$ temperature

$\mathrm{A}_{2} \mathrm{~B}_{2}=4 \%$ catalyst, $300^{\circ} \mathrm{C}$ temperature
$\mathrm{A}_{3} \mathrm{~B}_{1}=6 \%$ catalyst, $250^{\circ} \mathrm{C}$ temperature

$\mathrm{A}_{3} \mathrm{~B}_{2}=6 \%$ catalyst, $300{ }^{\circ} \mathrm{C}$ temperature

$\mathrm{A}_{4} \mathrm{~B}_{1}=8 \%$ catalyst, $250^{\circ} \mathrm{C}$ temperature

$\mathrm{A}_{4} \mathrm{~B}_{2}=8 \%$ catalyst, $300{ }^{\circ} \mathrm{C}$ temperature
In the upgrading of $\mathrm{CBO}$ qualities, it also ended up with the residue, which in portion ranged about 56.59$84.19 \%$. The highest portion of residue from the CBO's cracking was obtained at $250{ }^{\circ} \mathrm{C}$ without a catalyst, while the lowest was at the $300{ }^{\circ} \mathrm{C}$ with a $6 \% \mathrm{Ni} / \mathrm{NZA}$ catalyst.

The possible explanation for such occurring phenomena above was that the residue from the CBO's cracking at $250^{\circ} \mathrm{C}$ without catalyst was in greater part still in viscous form like tar, and could be cracked down at $300{ }^{\circ} \mathrm{C}$, thereby cracking at $300^{\circ} \mathrm{C}$ with the catalyst is able to convert the $\mathrm{CBO}$ to lower molecular weight fractions and less viscous form as a liquid. Meanwhile, the residues at $300{ }^{\circ} \mathrm{C}$ were initially in a very thick form like mud, and subsequently, when the heating was continued to the cracking completion, it would induce the CBO's cracking and carbonization more intensively. It is also generating more low molecular weight products and lower the residue portion in the form of mostly a solid charcoal.

From this research that at higher temperature with catalyst use, it could intensify the cracking action on converting the CBO's through degradation to simpler and lower molecular weight compounds, thereby lowering the residue portion and conversely increasing the product yield. The situation was on the contrary at lower cracking temperature and especially without a catalyst.

The cracking process in this research was able to convert as much as $15.81-43.40 \%$ of the $\mathrm{CBO}$ (Appendix 1) into the mixed liquid forms (6.67-30.72\%), and the rest escaped as non-condensable gases/vapors (7.28-12.75\%). As much as $1.52-26.42 \%$ of those $6.67-30.72 \%$ mixed forms were as the $\mathrm{CBO}$ converted to fuel.

\section{The $\mathrm{pH}$ of the upgraded $\mathrm{CBO}$}

The result showed that the $\mathrm{pH}$ of the upgraded $\mathrm{CBO}$ into fuel ranged from about 2.86-3.53 (Table 2). The lowest $\mathrm{pH}$ occurred to the fuel that resulted from CBO's cracking at $250^{\circ} \mathrm{C}$ without catalyst use, while the highest $\mathrm{pH}$ was obtained at $300{ }^{\circ} \mathrm{C}$ with $6 \% \mathrm{Ni} / \mathrm{NZA}$ catalyst use. This result indicates that high temperature with Ni/NZA catalyst brought about the fuel with higher $\mathrm{pH}$. These $\mathrm{pH}$ values are entirely still in the common $\mathrm{pH}$ range (2.8-4.0) of bio-oil chemically converted from most biomass materials [21].

Such low $\mathrm{pH}$ value indicates the presence of organic acids in CBO-derived fuel generated from the further degradation of the CBO's chemical compounds, which previously were already in degraded/depolymerized 
forms (e.g., cellulose, hemicellulose, lignin, and extractives [especially residual palm oil/fat]) following the OPEFB's pyrolysis.

The CBO's cracking at $300{ }^{\circ} \mathrm{C}$ aided by $6 \% \mathrm{Ni} / \mathrm{NZA}$ catalyst brought about the situation that those organic acids might be broken down to non-acidic (neutral) or weak-acid compounds with much lower molecular weight (e.g., hydrocarbon, aldehyde, ketone, slightly acidic phenols, and neutral hydrocarbons), thereby rendering the produced fuel less acidic or increasing the fuel $\mathrm{pH}$ until it achieved the highest (3.54). This is in line with the data in Appendix 1 for the treatment using $6 \% \mathrm{Ni} / \mathrm{NZA}$ at $300^{\circ} \mathrm{C}$, $5.82 \%$ acid compound obtained, lower than the other treatments. In relevant, according to Wang [22], the $\mathrm{pH}$ value of bio-oil typically ranged about $2-3$, due to the presence of carboxylic acids such as formic acid and acetic acid.

The overall $\mathrm{pH}$ of the fuel produced from the CBO's cracking was entirely greater than the $\mathrm{pH}$ of raw bio-oil or $\mathrm{CBO}$ that resulted from the OPEFB's pyrolysis (Table 2). This indicates that the organic acids in the $\mathrm{CBO}$ in part underwent further chemical breakdown during the CBO's cracking into numerously much lower molecular-weight compounds as among others neutral or rather neutral hydrocarbons in the cracking results (e.g., fuel). Bio-oil fuels with low $\mathrm{pH}$ value are less desirable, as they can lead to the corrosion of metal equipment such as conducting pipes, burner devices, and other metal-made apparatus.

\section{The specific gravity of the upgraded $C B O$}

The specific gravity of fuel ranged from about $0.990-$ 1.001 (Table 2). The lowest specific gravity occurred to the fuel produced from the CBO's cracking at $300{ }^{\circ} \mathrm{C}$ with an $8 \% \mathrm{Ni} / \mathrm{NZA}$ catalyst. Meanwhile, the highest specific gravity was achieved at $250{ }^{\circ} \mathrm{C}$ without a catalyst.

These overall fuel's specific gravity values were entirely higher than the specific gravity of OPEFB's upgraded bio-oil into fuel, which reached 0.851, as conducted in another study [23]. As such, the upgraded bio-oil was produced through cracking of the bio-oil under high pressure by adding hydrogen $\left(\mathrm{H}_{2}\right)$ gas and using the ZSM-5 catalyst. Presumably, such high fuel's specific gravity achieved in this research could be attributed to the absence of high pressure and due to not adding $\mathrm{H}_{2}$ gas. In general, the specific gravity of the particular type of $\mathrm{CBO}$ produced from biomass pyrolysis reached as high as 1.2, and the specific gravity of bio-oil that resulted from the sawdust's biomass pyrolysis achieved even higher (1.3) [24].

\section{The viscosity of the upgraded $C B O$}

The measurement results on fuel's viscosity revealed the variation in the range of 9.5-21.3 cSt (Table 2 ). The lowest viscosity occurred at the fuel produced from CBO's cracking at $250{ }^{\circ} \mathrm{C}$ with a $4 \% \mathrm{Ni} / \mathrm{NZA}$ catalyst while the highest fuel viscosity was from the implementation of $300{ }^{\circ} \mathrm{C}$ temperature without a catalyst. The fuel viscosity $(9.5-11.5 \mathrm{cSt})$ at $250{ }^{\circ} \mathrm{C}$ for $\mathrm{CBO}$ cracking tended to be smaller than the fuel viscosity $(11.7-21.3 \mathrm{cSt})$ at $300{ }^{\circ} \mathrm{C}$. On the contrary, at $250{ }^{\circ} \mathrm{C}$ as well as at $300^{\circ} \mathrm{C}$ in the CBO's cracking, the fuel viscosity without catalyst $(11.5-21.3 \mathrm{cSt})$ was greater than fuel viscosity with $\mathrm{Ni} / \mathrm{NZA}$ catalyst $(9.5-14.3 \mathrm{cSt}$ ).

It has been strongly confirmed that the use of $\mathrm{Ni} / \mathrm{NZA}$ catalyst assisted in intensifying the conversion of CBO's to more numerous fragmented/simpler and low molecular weight compounds. It is also explained that the CBO's chemical breakdown brought about the produced fuel with low viscosity, due to the presence of $\mathrm{Ni} / \mathrm{NZA}$ catalyst.

In general, according to Vispute [25], the high viscosity of $\mathrm{CBO}$ is due to a large number and high concentration of high molecular weight compounds inside. Long-chain molecule compounds tended to entangle with each other, creating viscous mass, increasing the fuel viscosity.

The fuel viscosity in these research results (9.5$21.3 \mathrm{cSt}$ ) was still much higher than the viscosity as experimented by Zhang et al. [26] who performed the upgrading of bio-oil through the pine wood's bio-oil cracking with $10 \%$ silica sulphuric acid (SSA) catalyst $(\mathrm{w} / \mathrm{w})$ in the reactor that was pressurized for $3 \mathrm{~h}$ at $120^{\circ} \mathrm{C}$. Such pressurized cracking brought about the upgraded bio-oil with low viscosity $(5.5 \mathrm{cSt})$ and also low specific gravity (0.89). However, if compared to the viscosity of $\mathrm{CBO}(57.7 \mathrm{cSt})$ that resulted from OPEFB's pyrolysis, the overall viscosity of the upgraded $\mathrm{CBO}$ into fuel was still much lower. This again confirms that $\mathrm{CBO}$ 's cracking at 
elevated temperature $\left(250\right.$ and $300^{\circ} \mathrm{C}$ ) aided by Ni/NZA catalyst (4-8\%) could induce the conversion of CBO's compounds to numerously simpler and low molecularweight compounds and lowering the fuel viscosity.

Although the fuel that resulted from the upgrading of OPEFB's CBO indicatively cannot be used as fuel for running vehicles or other transportation means that use piston-driven engines due to its still high viscosity, it seems still useful after being blended with petroleum's heavy fuel for operating fuel-fired boilers [27].

\section{The heating value of the upgraded crude bio-oil}

The calorific values from the CBO's cracking were ranged from about 17.22-30.85 MJ/kg (Table 2). The lowest calorific value was encountered at the fuel produced from the CBO's cracking at $250{ }^{\circ} \mathrm{C}$ without catalyst, while the highest was at $300{ }^{\circ} \mathrm{C}$ with a $6 \%$ $\mathrm{Ni} / \mathrm{NZA}$ catalyst. These phenomena strongly confirm the previous indication that high cracking temperature $\left(300{ }^{\circ} \mathrm{C}\right)$ aided by the Ni/NZA catalyst intensified more $\mathrm{CBO}$ 's conversion and therefore generated fragmented and low molecular weight compounds.

When the fuel with such numerous fragmented low molecular-weight compounds was combusted, the heating potency of each compound would combine and add up to each other, accordingly released a considerable amount of energy, and hence, caused higher fuel's calorific value. The calorific values of $\mathrm{CBO}$-derived fuel in these results were, in part, still in the range of calorific values for the upgraded bio-oil into fuel that resulted from the hydrocracking of bio-oil or hydrodeoxygenation (HDO) using zeolite catalyst, which reached $21-36 \mathrm{MJ} / \mathrm{kg}$. Further, the calorific values of $\mathrm{CBO}$-derived fuel were considerably lower than the calorific values of fuel that resulted from bio-oil's HDO process (42-45 MJ/kg) [28].

Such a high calorific value of the HDO's upgraded bio-oil into fuel was attributed to the HDO's cracking process, which used hydrogen gas and implemented highpressure in a 1-10 MPa range [29]. It seems that such HDO's cracking intensified the bio-oil's cracking more severely, generating the amount of short-chain hydrocarbon alkanes such as octane $\left(\mathrm{C}_{8} \mathrm{H}_{18}\right)$ and nonane $\left(\mathrm{C}_{9} \mathrm{H}_{20}\right)$ in the produced fuel. Accordingly, when those numerous short-chain alkanes were combusted together, their released energy could add up to each other and end up with high fuel's calorific value. High heating values of particular combustible materials or fuels are desired, because it can provide a considerable amount of energy or power for operating fuel-run devices, such as fuelpowered vehicles, electric generators, stoves, boilers, and furnaces.

\section{Chemical Compounds in the Produced Fuel}

Appendix 1 discloses the list of organic compounds present in the fuel that resulted from the upgrading of $\mathrm{CBO}$, which was identified through the GC-MS analysis. It turns out that particular aromatic groups such as hydrocarbon, phenols, aliphatic, furan, ester, acids, ketones, and alcohols were identified, which contained significant amounts of phenolic compounds. These phenolic compounds, as identified, were due to the lignin degradation during the CBO's cracking process, which was responsible for the higher content of carbon and hydrogen fractions in the produced fuel and contributed to the fuel's higher heating values [30].

The cracking's liquid product also contained aromatic hydrocarbons (e.g., benzene and benzene derivatives) and aliphatic hydrocarbons (e.g., hexane, tridecane, octadecane, hexadecane, etc.). The most numerous aliphatic and aromatic hydrocarbons were encountered in the fuel resulted from CBO's cracking at $300^{\circ} \mathrm{C}$ temperature with $8 \% \mathrm{Ni} / \mathrm{NZA}$ catalyst, compared to the number of which resulted from the cracking with the other treatment. On the other hand, more numerous hydrocarbons were found in the fuel from CBO's cracking at $300{ }^{\circ} \mathrm{C}$ temperature, aided by $8 \% \mathrm{Ni} / \mathrm{NZA}$ catalyst), compared to the number of hydrocarbons from CBO's cracking at $250{ }^{\circ} \mathrm{C}$ with also $8 \% \mathrm{Ni} / \mathrm{NZA}$ catalyst. This again confirms that the use of higher temperatures during the $\mathrm{CBO}$ 's cracking brought out the produced fuel with more numerous hydrocarbon compounds inside and increasing the fuel heating/calorific value.

To improve such unsatisfactory fuel qualities, it is recommended that the modification of CBO's cracking process is necessary by implementing among others higher pressure, $\mathrm{H}_{2}$-gas addition, and higher 
temperature. Relevantly, according to Huber et al. [31] in the biomass's conversion through a cracking process into fuel which was suitable in use for transportation means that used piston engines, it necessitates the biomass cracking process at temperatures as high as $300-600{ }^{\circ} \mathrm{C}$ and implementing high pressure that reached $14 \mathrm{MPa}$ (140 bar).

Frety et al. [32] suggested that implementing higher hydrogen gas pressure during the biomass' hydrocracking process would increase the production of alkane compounds. However, the hydrocracking process seems still an expensive way in an upgrading attempt to produce fuel with high energy and other improved qualities, because it requires the involvement of hydrogen-gas use and proper reactor equipment.

\section{- CONCLUSION}

The optimum CBO's cracking condition was determined to be the temperature of $300{ }^{\circ} \mathrm{C}$ with $6 \%$ $\mathrm{Ni} / \mathrm{NZA}$ catalyst use. The fuel yield product, calorific value, $\mathrm{pH}$, specific gravity, and viscosity were $26.42 \%$, $30.85 \mathrm{MJ} / \mathrm{kg}, 3.54,0.995,14.3 \mathrm{cSt}$, respectively. Several characteristics of fuel were regarded as satisfactory, except $\mathrm{pH}$ and viscosity.

\section{- REFERENCES}

[1] Luo, H., Bao, L., Kong, L., and Sun, Y., 2017, Low temperature microwave-assisted pyrolysis of wood sawdust for phenolic rich compounds: Kinetics and dielectric properties analysis, Bioresour. Technol., 238, 109-115.

[2] Dermibas, A., 2008, Biodiesel: A Realistic Fuel Alternative for Diesel Engines, Springer-Verlag London Limited, London, UK.

[3] Choi, J.H., Woo, H.C., and Suh, D.J., 2014, Pyrolysis of seaweeds for bio-oil and bio-char production, Chem. Eng. Trans., 37, 121-126.

[4] Hassan, E.B., Abou-Yousef, H., Steele, P., and ElGiar, E. 2016, Characterization of bio-oils from the fast pyrolysis of white oak and sweetgum, Energy Sources Part A, 38 (1), 43-50.

[5] Brown, R.C., and Holmgren, J., 2013, Fast pyrolysis and bio-oil upgrading, https://www.researchgate.net/ profile/Robert_Brown31/publication/204979128_Fast _pyrolysis_and_bio-oil_upgrading/links/00b7d52b 21146924c1000000.pdf.

[6] Liu, W.J., Zhang, X.S., Qv, Y.C., Jiang, H., and Yu, H.Q., 2012, Bio-oil upgrading at ambient pressure and temperature using zero valent metals, Green Chem., 14 (8), 2226-2233.

[7] Wu, J., Shi, J., Fu, J., Leidl, J.A., Hou, Z., and Lu, X., 2016, Catalytic decarboxylation of fatty acids to aviation fuels over nickel supported on activated carbon, Sci. Rep., 6 (1), 27820.

[8] Hovhannisyan, V.A., Dong, C.Y., Lai, F.J., Chang, N.S., and Chen, S.J., 2019, Natural zeolite for adsorbing and release of functional materials, $J$. Biomed. Opt., 23 (9), 091411.

[9] Sriningsih, W., Saerodji, M.G., Trisunaryanti, W., Triyono, Armunanto, R., and Falah, I.I., 2014, Fuel production from LDPE plastic waste over natural zeolite supported $\mathrm{Ni}, \mathrm{Ni}-\mathrm{Mo}, \mathrm{Co}$ and $\mathrm{Co}-\mathrm{Mo}$ metals, Procedia Environ. Sci., 20, 215-224.

[10] Yang, H., Wang, Q., Sang, Y., Fan, G., and Xu, Q., 2014, Online upgrading of bio-oil pyrolyzed form by shrub residues, Asian J. Chem., 26 (1), 247-250.

[11] Singh, R.K., and Shadangi K.P., 2011, Liquid fuel from castor seeds by pyrolysis, Fuel, 90 (7), 25382544.

[12] Bahri, S., Sunarno, Muhdarina, and Anugra, R.D., 2011, Catalytic pyrolysis using catalyst nickelnatural zeolite $(\mathrm{Ni} / \mathrm{NZA})$ on conversion of biomass to bio-oil, 2011 International Conference \& Utility Exhibition on Power and Energy Systems: Issues and Prospects for Asia (ICUE), Pattaya City, Thailand, 28-30 September 2011.

[13] Dusselier, M., and Davis, M.E., 2018, Smal-pore zeolites: Synthesis and catalysis, Chem. Rev., 118 (1), 5265-5329.

[14] Trisunaryanti, W., Triyono, Armunanto, R., Hastuti, L.P., Ristiana, D.D., and Ginting, R.V., 2018, Hydrocracking of a-cellulose using $\mathrm{Co}, \mathrm{Ni}$, and Pd supported on mordenite catalysts, Indones. J. Chem., 18 (1), 166-172.

[15] Naqvi, S.R., Uemura, Y., Yusup, S., Sugiur, Y., Nishiyama, N., and Naqvi, M., 2015, The role of zeolite structure and acidity in catalytic 
deoxygenation of biomass pyrolysis vapors, Energy Procedia, 75, 793-800.

[16] Salim, I., Trisunaryanti, W., Triyono, and Arryanto, Y., 2016, Hydrocracking of coconut oil into gasoline fraction using $\mathrm{Ni} /$ modified natural zeolite catalyst, Int. J. ChemTech Res., 9 (4), 492-500.

[17] Houas, A., Lachheb, H., Ksibi, M., Elaloui, E., Guillard, C., and Herrmann, J.M., 2001, Photocatalytic degradation pathway of methylene blue in water, Appl. Catal., B, 31 (2), 145-157.

[18] Yao, D., Yang, H., Chen, H., and Williams, P.T., 2018, Investigation of nickel-impregnated zeolite catalysts for hydrogen/syngas production from the catalytic reforming of waste polyethylene, Appl. Catal., B, 227, 477-487.

[19] Ichsan, G.M., Nugrahaningtyas, K., Widjonarko, D., and Rahmawati, F., 2019, Structure and morphology of the $(\mathrm{Ni}, \mathrm{Co}) \mathrm{Mo} /$ Indonesian natural zeolite, IOP Conf. Ser. Mater. Sci. Eng., 578, 012009.

[20] Hessel, V., Anastasopoulou, A., Wang, Q., Kolb, G., and Lang, J., 2013, Energy, catalyst and reactor considerations for (near) -industrial plasma processing and learning for nitrogen-fixation reactions, Catal. Today, 211, 9-28.

[21] Sadaka, S., and Boateng, A., 2009, Pyrolysis and biooil, Agriculture and Natural Resources, Cooperative Extension Service, University of Arkansas, United States Department of Agriculture and County Governments Cooperating.

[22] Wang, S., 2013, "High-efficiency separation of biooil" in Biomass Now: Sustainable Growth and Use, Eds. Matovic, M.D., IntechOpen, Croatia, 401-418.

[23] Hew, K.L., Tamidi, A.M., Yusup, S., Lee, K.T., and Ahmad, M.M., 2010, Catalytic cracking of bio-oil to organic liquid product (OLP), Bioresour. Technol., 101 (22), 8855-8858.

[24] Bardalai, M., and Mahanta, D.K., 2015, A review of physical properties of biomass pyrolysis oil, Int. J. Renew. Energy Res., 5 (1), 277-286.

[25] Vispute, T., 2011, Pyrolysis oils: Characterization, stability analysis, and catalytic upgrading to fuels and chemicals, Dissertations, University of Massachusetts, USA.

[26] Zhang, Z., Sui, S., Wang, F., Wang, Q., and Pittman, C.U., 2013, Catalytic conversion of bio-oil to oxygen-containing fuels by acid-catalyzed reaction with olefins and alcohols over silica sulfuric acid, Energies, 6 (9), 4531-4550.

[27] Hou, S.S., Huang, W.C., Rizal, F.M., and Lin, T.H., 2016, Co-firing of fast pyrolysis bio-oil and heavy fuel oil in a $300-\mathrm{kW}_{\text {th }}$ furnace, Appl. Sci., 6 (11), 326.

[28] Mortensen, P.M., Grunwaldt, J.D., Jensen, P.A., Knudsen, K.G., and Jensen, A.D., 2011, A review of catalytic upgrading of bio-oil to engine fuels, $A p p l$. Catal., A, 407 (1-2), 1-19.

[29] Daudin, A., Bournay, L., and Chapus, T., 2010, Method of converting effluents of renewable origin into the fuel of excellent quality by using a molybdenum-based catalyst, US Patent 20100163458A1, 1 November 2010.

[30] Nanda, S., Mohanty, P., Kozinski, J.A., and Dalai, A.K., 2014, Physico-chemical properties of bio-oils from pyrolysis of lignocellulosic biomass with high and slow heating rate, Energy Environ. Res., 4 (3), 21-32.

[31] Huber, G.W., Sara, I., and Corma, A., 2006, Synthesis of transportation fuels from biomass, Chem Rev., 106 (9), 4044-4098.

[32] Frety, R., da Rocha, M.G.C., Brandão, S.T., Pontes, L.A.M., Padilha, J.F., Borgesc, L.E.P., and Gonzalez, W.A., Cracking and hydrocracking of triglycerides for renewable liquid fuels: Alternative processes to transesterification, J. Braz. Chem. Soc., 22 (7), 12061220 . 